\title{
Arrangement of the Respiratory Burst Oxidase in the Plasma Membrane of the Neutrophil
}

\author{
Gregory L. Babior, Richard E. Rosin, B. Jane McMurrich, \\ Wendy A. PETERS, and Bernard M. BABIOR, Blood Research Laboratory and \\ the Department of Medicine, Tufts-New England Medical Center, \\ Boston, Massachusetts 02111
}

\begin{abstract}
A B S T RA C T Evidence was obtained regarding the way the $\mathrm{O}_{2}^{-}$-forming NADPH oxidase of human neutrophils is arranged within the plasma membrane. $\mathrm{O}_{2}^{-}$ production by particles from zymosan-activated human neutrophils rose two- to threefold when the particles were assayed in the presence of appropriate concentrations of Triton X-100. The portion of activity revealed by the detergent was not affected by treating the particles with trypsin or with $p$-chloromercuribenzene sulfonate, a nonpenetrating sulfhydryl reagent, but the activity detectable in the absence of detergent was abolished by these treatments. $\mathrm{O}_{2}^{-}$production by phagocytic vesicles was not augmented by detergent, and was almost entirely eliminated by tryptic digestion of the vesicles regardless of whether or not detergent was present during the assay. These results suggest that the $\mathrm{O}_{\mathbf{2}}^{-}$-forming oxidase is embedded in the plasma membrane with a portion extending into the cytoplasm and the rest buried in the lipid bilayer. It is proposed that the pyridine nucleotide-binding site is located on the cytoplasmic extension and the oxygen binding site is on the intramembranous portion of the enzyme.
\end{abstract}

\section{INTRODUCTION}

When a microorganism is ingested by a neutrophil, it becomes tightly enclosed within a vesicle whose wall consists of a portion of what was originally the plasma membrane of the phagocyte. Within this plasma membrane is an oxidase that catalyzes the one-electron reduction of oxygen to $\mathrm{O}_{2}^{-}$at the expense of NADPH $(1-6)$ :

$$
2 \mathrm{O}_{2}+\mathrm{NADPH} \rightarrow 2 \mathrm{O}_{2}^{-}+\mathrm{NADP} .
$$

This oxidase is dormant in the resting cells, but when activated, as by the exposure of the neutrophil to an opsonized bacterium, it is responsible for the production of large quantities of $\mathrm{O}_{2}^{-}$and other partially reduced oxygen derivatives that enter the phagocytic

Received for publication 26 November 1980 and in revised form 13 February 1981. vesicle and participate in the destruction of the ingested microorganism (7-9).

Experiments with cytochalasin B-paralyzed neutrophils have shown that all the oxygen consumed in the respiratory burst can be accounted for as $\mathrm{O}_{2}^{-}$liberated into the external medium (10). Quantitative recovery of $\mathrm{O}_{2}^{-}$would be unlikely if the $\mathrm{O}_{2}^{-}$were being first released into the cytoplasm, because under these circumstances the superoxide dismutase of the neutrophil (11) would almost certainly destroy at least part of the $\mathrm{O}_{2}^{-}$before it could diffuse out through the plasma membrane. This finding therefore seems to indicate that the $\mathrm{O}_{2}^{-}$-forming reaction is taking place at the outer surface of the cell. The reducing agent, however, is a cytoplasmic constituent, and must donate its electrons to an acceptor no more remote from the cytoplasm than the inner face of the plasma membrane. Taken together, these observations suggest that the NADPH oxidase is a transmembrane enzyme, picking up an electron at the inner face of the membrane and transporting it through to an oxygen molecule at the outer face. It was to test this idea that the studies reported here were performed.

\section{METHODS}

Cytochrome $c$ (type VI), bovine erythrocyte superoxide dismutase, trypsin, soybean trypsin inhibitor (SBTI), ${ }^{1}$ DNAse type I (chromatographically purified), latex particles $(0.81$ $\mu \mathrm{m}$ Diam), zymosan, flavin adenine dinucleotide (FAD), pyridine nucleotides, $p$-chloromercuribenzene sulfonate (pCMBS) and phorbol myristate acetate (PMA) were obtained from Sigma Chemical Co., St. Louis, MO. The PMA was dissolved in dimethylsulfoxide $(2 \mathrm{mg} / \mathrm{ml})$ and stored at $-70^{\circ} \mathrm{C}$. Hanks' balanced salt solution (HBSS) was purchased from Gibco Laboratories, Grand Island, N. Y., and Triton X-100 was obtained from New England Nuclear, Boston, Mass. Other reagents were the best grade commercially available, and were used without further purification.

${ }^{1}$ Abbreviations used in this paper: FAD, flavin adenine dinucleotide; HBSS, Hanks' balanced salt solution; pCMBS, $p$-chloromercuribenzene sulfonate; PMA, phorbol myristate acetate; SBTI, soybean trypsin inhibitor. 
$\mathrm{O}_{2}^{-}$-forming particles and phagosomes. These were obtained from human neutrophils prepared by dextran sedimentation and differential centrifugation (12) and suspended in $0.25 \mathrm{M}$ sucrose adjusted to $\mathrm{pH} 7.4$ with $0.1 \mathrm{M} \mathrm{NaOH}$. $\mathrm{O}_{2}^{-}$-forming particles were prepared from zymosan-activated neutrophils by sonication and centrifugation as described by Gabig and Babior (6), and suspended in $0.25 \mathrm{M}$ sucrose $(\mathrm{pH} \mathrm{7.4)}$ at $1.0 \mathrm{mg}$ protein $/ \mathrm{ml}$.

$\mathrm{O}_{2}^{-}$-forming phagosomes were prepared by a modification of the method of Segal et al. (13). Latex particles were washed once with $0.9 \% \mathrm{NaCl}$, then incubated for $30 \mathrm{~min}$ at $25^{\circ} \mathrm{C}$ in $0.9 \% \mathrm{NaCl}$ containing $50 \mu \mathrm{l} / \mathrm{ml}$ stock PMA solution. The particles were then centrifuged and resuspended in HBSS to a final concentration of $4 \times 10^{10}$ particles $/ \mathrm{ml}$, determined by measuring the turbidity of the suspension at $620 \mathrm{~nm}$ using the commercial particle suspension as standard. To $0.5 \mathrm{ml}$ of the PMA-treated latex particles was added $0.02 \mathrm{ml}$ of $0.1 \mathrm{M}$ $\mathrm{NaN}_{3}$ followed by $1.5 \mathrm{ml}$ neutrophil suspension $\left(1.33 \times 10^{8}\right.$ cells $/ \mathrm{ml}$ ). This mixture was incubated for $7 \mathrm{~min}$ at $37^{\circ} \mathrm{C}$. The incubation was terminated by the addition of $15 \mathrm{ml}$ of ice-cold HBSS. Cells were isolated by centrifugation at $125 \mathrm{~g}$ for $12 \mathrm{~min}$ at $4^{\circ} \mathrm{C}$, suspended in $5 \mathrm{ml}$ of $11.2 \%$ sucrose ( $\mathrm{pH} 7.4$ ), and disrupted by hand homogenization (100 strokes) in a $10-\mathrm{ml}$ Potter-Elvehjem homogenizer at $4^{\circ} \mathrm{C}$. Solid DNAse, $4 \mathrm{mg}$, was added to the resulting homogenate, which was incubated at $0^{\circ} \mathrm{C}$ for $10 \mathrm{~min} .12 \mathrm{ml}$ ice-cold $60 \%$ (wt/vol) sucrose ( $\mathrm{pH} \mathrm{7.4}$ ) was then added, and the diluted homogenate was placed in a $1 \times 3.5$-in polyallomer centrifuge tube. The homogenate was successively overlaid with $15 \mathrm{ml}$ of $33 \%$ (wt/vol) sucrose (pH 7.4) followed by $5 \mathrm{ml}$ of $11.2 \%$ (wt/vol) sucrose (pH 7.4), then centrifuged in an SW 28 swinging bucket rotor at $24,000 \mathrm{~g}$ for $20 \mathrm{~min}$ at $4^{\circ} \mathrm{C}$. Phagocytic vesicles accumulated at the interface between the two upper sucrose layers. The vesicles were carefully aspirated and diluted with distilled water to a final sucrose concentration of $0.25 \mathrm{M}$, as determined with a Fisher refractometer (Fisher Scientific Co., Pittsburgh, Pa.).

Measurement of $\mathrm{O}_{2}^{-}$production. $\mathrm{O}_{2}^{-}$production was measured by a modification of a previously described method (14). Reaction mixtures were prepared in a total volume of $2.0 \mathrm{ml}$, using $1.0 \mathrm{ml}$ HBSS as buffer. The reaction was begun by adding particles or phagosomes. Immediately, $1.0 \mathrm{ml}$ of reaction mixture was placed in a tube containing $10 \mu \mathrm{l}$ superoxide dismutase $(3 \mathrm{mg} / \mathrm{ml})$ to serve as reference. The remainder was incubated at room temperature for the desired time in the dark. The incubation was stopped with $10 \mu \mathrm{l}$ superoxide dismutase, and $\mathrm{O}_{2}^{-}$production was measured spectrophotometrically as dismutase-inhibitable cytochrome $c$ reduction as described elsewhere. In assays of $\mathrm{O}_{2}^{-}$production by phagosomes, the phagosomes were removed by centrifugation for $2 \mathrm{~min}$ in an Eppendorf microfuge prior to spectrometry.

Protein concentration. Protein concentration was determined by the method of Bradford (15).

Digestion with trypsin. Digestion with trypsin was conducted at $23^{\circ} \mathrm{C}$. Into each of six tubes was placed $0.6 \mathrm{ml}$ of particle suspension. The tubes were separated into pairs, one member of each pair receiving $0.1 \mathrm{ml} 40 \mu \mathrm{M}$ FAD plus $0.1 \mathrm{ml} 0.25 \mathrm{M}$ sucrose, and the other $0.1 \mathrm{ml}$ FAD plus $0.1 \mathrm{ml}$ $0.20 \%$ Triton X-100 in $0.25 \mathrm{M}$ sucrose. Particles in one pair of tubes were digested by adding to each tube $0.1 \mathrm{ml}$ freshly dissolved trypsin $(10 \mathrm{mg} / \mathrm{ml}$ in $0.25 \mathrm{M}$ sucrose $)$ and incubating for $10 \mathrm{~min}$. Digestion was stopped with $0.1 \mathrm{ml} \mathrm{SBTI}(15 \mathrm{mg} / \mathrm{ml}$ in $0.25 \mathrm{M}$ sucrose), and the tubes were placed on ice. Each of a second pair of tubes was incubated for $10 \mathrm{~min}$ with $0.2 \mathrm{ml}$ of a 1:1 mixture of trypsin and SBTI, then placed on ice. The other two tubes were received $0.2 \mathrm{ml} 0.25 \mathrm{M}$ sucrose, and were kept on ice throughout. Assays were then performed using $0.2-\mathrm{ml}$ portions of each sample in the assay mixture.

Treatment of phagosomes with trypsin was carried out by a similar procedure, except that incubations were carried out for $3 \mathrm{~min}$, and digestion was not carried out in the presence of Triton.

Treatment with $p C M B S$. pCMBS was dissolved in water, brought to pH 7.4 with $\mathrm{NaHCO}_{3}$, and diluted to $1 \mathrm{mM}$ to make up the stock solution. $\mathrm{O}_{2}^{-}$-forming particles were treated with this reagent by placing $0.9-\mathrm{ml}$ portions of particle suspension in centrifuge tubes and mixing them first with pyridine nucleotides (where indicated), then with water or pCMBS to bring the final volumes to $1.0 \mathrm{ml}$ and the final concentrations to those indicated in Results. Incubations were carried out for $2 \mathrm{~min}$ at $0^{\circ} \mathrm{C}$, then terminated by the addition of $1.0 \mathrm{ml}$ of $0.1 \mathrm{mM}$ glutathione. Particles were then isolated by centrifugation at $25,000 \mathrm{~g}$ for $20 \mathrm{~min}$ at $4^{\circ} \mathrm{C}$, washed once with $0.25 \mathrm{M}$ sucrose ( $\mathrm{pH} 7.4$ ), and finally suspended in the same medium. Assays were performed using $0.2-\mathrm{ml}$ portions of each sample as described below.

\section{RESULTS}

The superoxide-forming enzyme in neutrophil homogenates is found in vesicles of plasma membrane (4). In principle, such plasma membrane vesicles can consist of two populations: one in which the vesicle membrane is oriented as it was in the cell, with what was originally its outer surface facing the exterior (normal); and one in which its orientation is reversed, its inner or cytoplasmic surface facing the exterior (inverted). If in the neutrophil the oxidase is asymmetrically situated in the membrane, with its pyridine nucleotidebinding site in contact with the cytosol, then in the homogenate the pyridine nucleotide binding site will be facing the lumen in normal vesicles, but will be on the outer surface of inverted vesicles. Since NADPH, a large, charged molecule, is unlikely to penetrate into the lumen of the vesicles, only the oxidase activity of the inverted vesicles would be detectible under ordinary circumstances, assuming a vectorial orientation of the enzyme. Detection of the total oxidase activity would require the disruption of the vesicle structure. The oxidase should thus exhibit latency similar to that seen with lysosomal enzymes, the ratio of activities of intact and disrupted vesicles varying with the proportion of inverted vesicles in the total population.

This possibility was tested using Triton $\mathrm{X}-100$ as the vesicle-disrupting agent. When $\mathrm{O}_{2}^{-}$production by an active neutrophil homogenate was examined as a function of detergent concentration, an abrupt increase in activity was seen as the detergent reached its critical micellar concentration (16) (Fig. 1). The cellfree oxidase thus exhibits latency, a finding consistent with the idea that the enzyme is vectorially arranged in the plasma membrane.

The fact that the electron donor is in the cytoplasm while the production of $\mathrm{O}_{2}^{-}$takes place at the outer surface of the neutrophil, suggests that the oxidase may traverse the plasma membrane with its pyridine nucleotide-binding site extending into the cytoplasm and its oxygen-binding site projecting into the external environment. If this were the case, incubation of the 


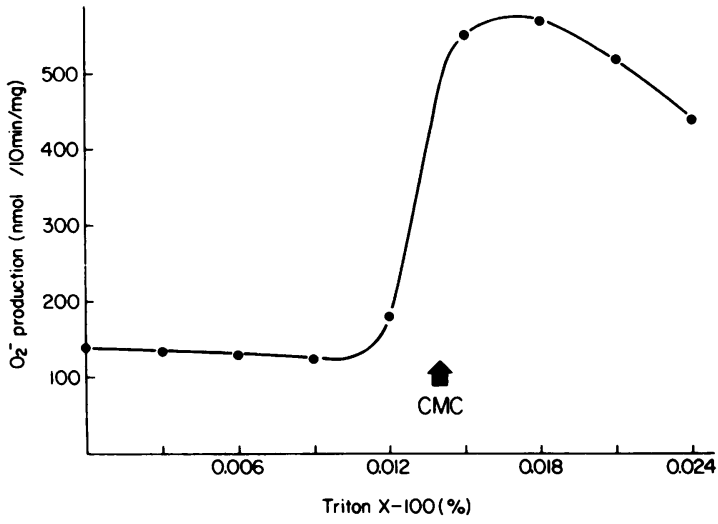

FIGURE $1 \quad \mathrm{O}_{2}^{-}$formation as a function of detergent concentration. Assay mixtures contained $0.2 \mathrm{ml}$ particles, $0.1 \mathrm{mM}$ NADPH, $20 \mu \mathrm{M}$ FAD, $80 \mu \mathrm{M}$ ferricytochrome $c$, and Triton X-100 at the concentrations shown. Assays were carried out for $10 \mathrm{~min}$ at room temperature. The results shown are representative of three separate experiments carried out with particles from three different donors. The critical micellar concentration for Triton X-100 in $0.075 \mathrm{M} \mathrm{NaCl}$ is indicated by the arrow.

$\mathrm{O}_{2}^{-}$-forming preparation with trypsin should eliminate the $\mathrm{O}_{2}^{-}$-forming activity in toto, abolishing that of normal and inverted vesicles through digestion of the oxygen-binding and pyridine nucleotide-binding regions, respectively. The results did not agree with this formulation. As shown in Table I, exposure to trypsin eliminated the $\mathrm{O}_{2}^{-}$-forming capacity expressed in the absence of detergent (overt activity), but had little effect on the activity revealed by Triton X-100 (latent activity). This result did not reflect an intrinsic difference in the trypsin sensitivity of the overt and latent fractions of the oxidase, because most of the latent activity was destroyed when the digestion was carried out in the presence of membrane-disrupting concentrations of Triton X-100. Neither was it an accident of timing, because a marked difference was found in the rates of inactivation of the overt and latent $\mathrm{O}_{2}^{-}$forming activities (Fig. 2). It therefore appears that the portion of the oxidase responsible for latent $\mathrm{O}_{2}^{-}$ production is protected by its situation in the membrane vesicle. These findings strongly suggest that the oxidase does not traverse the membrane, but is embedded in it with a portion projecting from only one face.

These results were confirmed in experiments with the nonpenetrating sulfhydryl reagent pCMBS. As shown in Table II, overt $\mathrm{O}_{2}^{-}$production is abolished by treatment with pCMBS, but latent $\mathrm{O}_{2}^{-}$production is unchanged. This finding strengthens the previous conclusion that the oxidase projects from only one face of the membrane, since results consistent with this idea were obtained with two nonpenetrating reagents having two very different modes of action.

Cohen et al. (17) have shown that phagocytic vesicles
TABLE I

Effect of Trypsin on the Activity of the $\mathrm{O}_{2}^{-}$-forming Particles

\begin{tabular}{lcc}
\hline \multicolumn{1}{c}{ Pretreatment } & $\begin{array}{c}\text { Triton X-100 } \\
\text { added to assay }\end{array}$ & $\mathrm{O}_{\mathbf{2}}^{-}$production \\
\hline & & $\%$ control \\
No Triton X-100 & - & $(100)$ \\
No protease & + & $265 \pm 79$ \\
No protease & - & $3 \pm 1$ \\
Trypsin & + & $230 \pm 83$ \\
Trypsin & - & $67 \pm 4$ \\
Trypsin plus SBTI & + & $255 \pm 95$ \\
Trypsin plus SBTI & & $260 \pm 63$ \\
Triton X-100 present & + & $10 \pm 1$ \\
No protease & + & $260 \pm 50$ \\
Trypsin & + & \\
Trypsin plus SBTI & & \\
\hline
\end{tabular}

Particles were incubated with trypsin, trypsin plus SBTI, or sucrose as described in Methods. Assay mixtures contained $0.2 \mathrm{ml}$ particles, $0.1 \mathrm{mM}$ NADPH, $20 \mu \mathrm{M}$ FAD, and $80 \mu \mathrm{M}$ ferricytochrome $c$. Where indicated, Triton X-100 was added to the assay mixture to bring the final concentration of detergent to $0.018 \%$. Assays were conducted for $10 \mathrm{~min}$ at room temperature. The three experiments were carried out with particles from three different donors. Rates of $\mathrm{O}_{2}^{-}$production in control samples were $345 \pm 73 \mathrm{nmol} / \mathrm{mg}$ per $10 \mathrm{~min}$ (mean $\pm \mathrm{SE}$ ). +/-, with/without.

from activated neutrophils are able to generate $\mathrm{O}_{2}^{-}$. Because of the way phagocytic vesicles are formed, their membranes will all be inverted, with proteins exposed to the external environment that normally project into the cytoplasm. Examining the effect of trypsin on $\mathrm{O}_{2}^{-}$production by such vesicles will provide evidence as to which face of the membrane the trypsin-sensitive portion of the oxidase projects from.

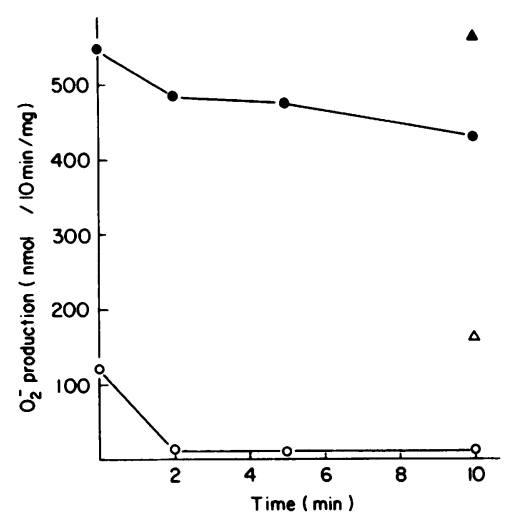

FIgure 2 Rate of destruction of overt and latent $\mathrm{O}_{2}^{-}$forming activity by trypsin. Particles were digested with trypsin for the times indicated. Assay mixtures contained $0.2 \mathrm{ml}$ particles, $0.1 \mathrm{mM}$ NADPH, $20 \mu \mathrm{M}$ FAD, $80 \mu \mathrm{M}$ ferricytochrome $c$, and either $0.018 \%$ Triton X-100 (-) or no detergent $(O)$. Assays were carried out for $10 \mathrm{~min}$ at room temperature. $\Delta, \Delta$, activity of particles diluted with sucrose and kept on ice (see Methods). 
TABLE II

Effect of $p C M B S$ on the Activity of $\mathrm{O}_{2}^{-}$-forming Particles

\begin{tabular}{lcc}
\hline \multirow{2}{*}{ Pretreatment } & $\begin{array}{c}\text { Triton X-100 } \\
\text { in assay }\end{array}$ & $\mathrm{O}_{2}^{-}$production \\
\hline \multirow{2}{*}{ None } & - & $\%$ control \\
& + & $(100)$ \\
pCMBS & - & $232 \pm 31$ \\
& + & $16 \pm 4$ \\
\hline
\end{tabular}

Particles were treated with $0.1 \mathrm{mM}$ pCMBS as described in Methods. Assay mixtures contained $0.2 \mathrm{ml}$ particles, $0.1 \mathrm{mM}$ NADPH, $20 \mu \mathrm{M}$ FAD, $80 \mu \mathrm{M}$ ferricytochrome $c$, and, where indicated, $0.018 \%$ Triton X-100. Assays were conducted for $10 \mathrm{~min}$ at room temperature. The three experiments were carried out with particles from three different donors. Rates of $\mathrm{O}_{2}^{-}$production in the control samples were $143 \pm 29 \mathrm{nmol} / \mathrm{mg}$ per $10 \mathrm{~min}$.

Table III shows that almost all the $\mathrm{O}_{2}^{-}$-forming activity of phagocytic vesicles was sensitive to trypsin. Triton $\mathrm{X}-100$ had little effect on $\mathrm{O}_{2}^{-}$production by either trypsin-treated or control vesicles, demonstrating that in these preparations all the $\mathrm{O}_{2}^{-}$-forming activity was overt, and confirming the homogeneous orientation of the membranes of phagocytic vesicles. These results indicate that the oxidase projects into the cytoplasm from the inner face of the plasma membrane.

It is reasonable to propose that the portion of the oxidase that projects out of the membrane contains the pyridine nucleotide-binding site. Evidence for this was sought by examining the effect of pyridine nucleotides on inactivation by pCMBS. The two reduced

TABLE III

Effect of Trypsin on $\mathrm{O}_{2}^{-}$Production by Phagocytic Vesicles

\begin{tabular}{|c|c|c|c|c|}
\hline \multirow[b]{2}{*}{ Pretreatment } & \multirow[b]{2}{*}{$\begin{array}{c}\text { Triton X-100 } \\
\text { in assay }\end{array}$} & \multicolumn{3}{|c|}{$\mathrm{O}_{2}^{--}$production } \\
\hline & & $\begin{array}{l}\text { Experi- } \\
\text { ment } 1\end{array}$ & $\begin{array}{l}\text { Experi- } \\
\text { ment } 2\end{array}$ & $\begin{array}{l}\text { Experi- } \\
\text { ment } 3\end{array}$ \\
\hline & & \multicolumn{3}{|c|}{ nmol/mg/20 min } \\
\hline No protease & - & 202 & 183 & 41 \\
\hline No protease & + & 168 & 132 & \\
\hline Trypsin & - & 35 & 20 & 12 \\
\hline Trypsin & + & 61 & 24 & \\
\hline Trypsin plus SBTI & - & 220 & 223 & 62 \\
\hline Trypsin plus SBTI & + & 312 & 219 & \\
\hline
\end{tabular}

Vesicles were incubated with trypsin, trypsin plus SBTI, or sucrose as described in Methods. Assay mixtures contained $1.0 \mathrm{ml}$ vesicles, $0.4 \mathrm{ml}$ buffer, $0.1 \mathrm{mM}$ NADPH, $20 \mu \mathrm{M}$ FAD, $80 \mu \mathrm{M}$ ferricytochrome $c$, and, where indicated, $0.018 \%$ Triton X-100, in a total volume of $2.0 \mathrm{ml}$. Assays were conducted for $20 \mathrm{~min}$ at room temperature. The three experiments were carried out with preparations from three different donors. Protein concentrations in the vesicle preparations were 145,173 , and $192 \mu \mathrm{g} / \mathrm{ml}$. pyridine nucleotides are substrates for the enzyme, and must therefore associate with its pyridine nucleotide-binding site, whereas the oxidized pyridine nucleotides are neither substrates nor inhibitors (18), suggesting that they do not associate with the pyridine nucleotide-binding site. Therefore, protection of the oxidase by reduced but not oxidized pyridine nucleotides would be consistent with the idea that the mercurial was acting on a sulfhydryl group near the pyridine nucleotide-binding site that was protected when the substrate was bound to the enzyme. This in turn would imply that the pyridine nucleotide-binding site is on the extramembranous portion of the oxidase. However, $\mathrm{O}_{2}^{-}$-forming particles that were treated with $5 \mu \mathrm{M}$ pCMBS, a concentration that reduced the activity of the particles to $39 \pm 11 \%$ of control $(n=6)$, were not protected by any of the four pyridine nucleotides at concentrations of $0.1 \mathrm{mM}$. Thus no conclusions can be drawn from this experiment as to the location of the pyridine nucleotide binding site on the enzyme.

\section{DISCUSSION}

The present studies suggest that the $\mathrm{O}_{2}^{-}$-forming oxidase is situated in the plasma membrane as shown in Fig. 3. This arrangement has the following features: (a) the oxidase is asymmetrically oriented with respect to the two faces of the plasma membrane; $(b)$ a portion of the oxidase extends into the cytoplasm, but no portion of the enzyme is in contact with the extracellular environment; $(c)$ the pyridine nucleotide-binding site is on the cytoplasmic extension, but the oxygen-binding site is located on the intramembranous portion of the enzyme.

Of these features, those most unequivocally supported by the present results are the asymmetry of orientation and the cytoplasmic extension. The existence of latency and the effect of detergent on $\mathrm{O}_{2}^{-}$ production by trypsin- and pCMBS-treated particles both indicate that the oxidase is asymmetrical with respect to the faces of the membrane. The destruction of almost all the $\mathrm{O}_{2}^{-}$-forming activity of the phagocytic vesicles by tryptic digestion shows that a portion of the oxidase has to extend sufficiently far out of the external (i.e., cytoplasmic) face of the phagosomal membrane to be susceptible to proteolysis.

Somewhat less conclusive is the evidence that the

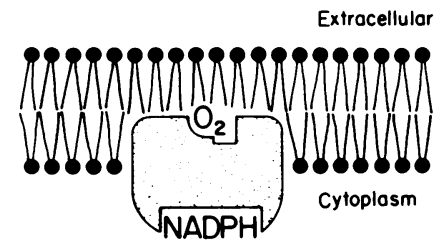

Figure 3 Model for the arrangement of the oxidase in the plasma membrane. 
oxidase does not extend into the extracellular environment. It seems very likely that the latent portion of the oxidase survives treatment of the particles with trypsin or pCMBS because the enzyme is not in contact with the extracellular environment and consequently is protected from nonpenetrating reagents acting on normal (as opposed to inverted) vesicles. The results do not, however, exclude the remote possibility that the enzyme possesses an extracellular extension that is resistant to both proteolysis and sulfhydryl reagents.

The most speculative feature of this model has to do with the locations of the substrate binding sites. The present observations provide no evidence as to this feature, so the locations proposed in the model are based on other considerations. With respect to the pyridine nucleotide binding site, it seems reasonable to postulate that it is on the cytoplasmic extension, since it must be accessible to NADPH, a constituent of the cytoplasm. Evidence concerning the location of the oxygen binding site is provided by the study of Root and Metcalf (10), in which it was shown that $\mathrm{O}_{2}^{-}$ produced by intact neutrophils does not pass through the cytoplasm on its way into the extracellular medium. This observation suggests that the oxygen-binding site is located on the intramembranous portion of the oxidase.

Other investigators have published observations that might be construed to indicate that a portion of the oxidase projects from the external face of the neutrophil membrane (19-21). There are alternative explanations, however, for all these observations. The cytochemical data of Briggs et al. (19) could be accounted for by postulating that $\mathrm{H}_{2} \mathrm{O}_{2}$ produced within the neutrophil membrane diffuses out to react with an extracellular $\mathrm{H}_{2} \mathrm{O}_{2}$-detecting system. Reports that the respiratory burst is abolished by treating neutrophils with nonpenetrating reagents prior to activation $(20,21)$ could be explained by postulating damage to the activating mechanism rather than the oxidase itself. The present findings are thus consistent with prior work dealing with the arrangement of the respiratory burst within the plasma membrane of the neutrophil.

\section{ACKNOWLEDGMENTS}

We thank Professor Filippo Rossi for his suggestion concerning the use of phorbol myristate acetate for the preparation of $\mathrm{O}_{2}^{-}$-forming phagocytic vesicles.

This work was supported in part by U. S. Public Health Service grant AI-11827.

\section{REFERENCES}

1. Hohn, D. C., and R. I. Lehrer. 1975. NADPH oxidase deficiency in X-linked chronic granulomatous disease. J. Clin. Invest. 55: 707-713.

2. Babior, B. M., J. T. Curnutte, and B. J. McMurrich. 1976. The particulate superoxide-forming system from human neutrophils. Properties of the system and further evidence supporting its participation in the respiratory burst. J. Clin. Invest. 58: 989-996.
3. McPhail, L. C., L. R. DeChatelet, and P. S. Shirley. 1976. Further characterization of NADPH oxidase activity of human polymorphonuclear leukocytes. J. Clin. Invest. 58: 774-780.

4. Dewald, B., M. Baggiolini, J. T. Curnutte, and B. M. Babior. 1979. Subcellular localization of the superoxideforming enzyme in human neutrophils. J. Clin. Invest. 63: 21-29.

5. Gabig, T. G., R. S. Kipnes, and B. M. Babior. 1978. Solubilization of the $\mathrm{O}_{2}^{-}$-forming activity responsible for the respiratory burst in human neutrophils. J. Biol. Chem. 253: 6663-6665.

6. Gabig, T. G., and B. M. Babior. 1979. The $\mathrm{O}_{2}^{-}$-forming oxidase responsible for the respiratory burst in human neutrophils. Properties of the solubilized enzyme. $J$. Biol. Chem. 254: 9070-9074.

7. Babior, B. M. 1978. Oxygen-dependent microbial killing by phagocytes. N. Engl. J. Med. 298: 659-668, 721-725.

8. Badwey, J. A., and M. L. Karnovsky. 1980. Active oxygen species and the functions of phagocytic leukocytes. Annu. Rev. Biochem. 49: 695-726.

9. Klebanoff, S. J. 1980. Oxygen metabolism and the toxic properties of phagocytes. Ann. Int. Med. 93: 480-489.

10. Root, R. K., and J. A. Metcalf. 1977. $\mathrm{H}_{2} \mathrm{O}_{2}$ release from human granulocytes during phagocytosis: relationship to superoxide anion formation and cellular catabolism of $\mathrm{H}_{2} \mathrm{O}_{2}$ : studies with normal and cytochalasin B treated cells. J. Clin. Invest. 60: 1266-1279.

11. Salin, M. L., and J. M. McCord. 1974. Superoxide dismutase in polymorphonuclear leukocytes. J. Clin. Invest. 54: 1005-1009.

12. Curnutte, J. T., and B. M. Babior. 1974. Biological defense mechanisms. The effect of bacteria and serum on superoxide production by granulocytes. J. Clin. Invest. 53: $1662-1672$.

13. Segal, A. W., J. Dorling, and S. Coade. 1980. Kinetics of fusion of the cytoplasmic granules with phagocytic vacuoles in human polymorphonuclear leukocytes. $J$. Cell Biol. 85: 42-59.

14. Babior, B. M., and R. S. Kipnes. 1977. Superoxideforming enzyme from human neutrophils: evidence for a flavin requirement. Blood. 50: 517-524.

15. Bradford, M. M. 1976. A rapid and sensitive method for the quantitation of microgram quantities of protein utilizing the principle of protein-dye binding. Anal. Biochem. 72: 248-254.

16. Ray, A., and G. Nemethy. 1971. Effects of ionic protein denaturants on micelle formation by non-ionic detergents. J. Am. Chem. Soc. 93: 6787-6793.

17. Cohen, H. J., P. E. Newburger, and M. E. Chovaniec, 1980. NAD(P)H-dependent superoxide production by phagocytic vesicles from guinea pig and human granulocytes. J. Biol. Chem. 255: 6584-6588.

18. Babior, B. M., and W. A. Peters. 1981. The $\mathrm{O}_{2}^{-}$-producing enzyme of human neutrophils: further properties. $J$. Biol. Chem. 256: 2321-2323.

19. Briggs, R. T., D. B. Drath, M. L. Karnovsky, and M. J. Karnovsky. 1975. Localization of NADH oxidase on the surface of human polymorphonuclear leukocytes by a new cytochemical method. J. Cell Biol. 67: 566-586.

20. Goldstein, I. M., M. Cerquiera, S. Lind, and H. B. Kaplan. 1977. Evidence that the superoxide-generating system of human leukocytes is associated with the cell surface. J. Clin. Invest. 59: 249-254.

21. Tsan, M-F., and P. A. McIntyre. 1976. The requirement for membrane sialic acid in the stimulation of superoxide production during phagocytosis by human polymorphonuclear leukocytes. J. Exp. Med. 143: 1308-1316. 